\title{
The Determinants of Interdistrict Labour In-migration in Pakistan, 1971-1980
}

\begin{abstract}
ANDREW P. BARKLEY
The movement of labour from one location to another in Pakistan has increased in recent years. This article begins by reviewing the previous literature pertinent to labour migration within Pakistan. Next, a migration equation at the aggregate level is specified, based on the expected socio-economic determinants of labour migration and data availability.

Regression analysis was used to identify and quantify the determinants of interdistrict migration in Pakistan during the period 1971-1980. The results demonstrate that one of the major determinants of migration into a district was the percent of previous migrants in a district's population. Interdistrict migration was also significantly associated with the socio-economic variables of urbanization, population density, and literacy rates.

The research presented here provides evidence that the movement of labour between districts in Pakistan is towards locations of superior socio-economic conditions. Migration was found to become more responsive to urbanization, population density, and literacy rates over time, and less responsive to previous migration over time. Given the huge increase in productivity in the agricultural sector brought about by the Green Revolution, the movement of workers out of agricultural areas and into industrial areas is expected to continue into the future. This rural-to-urban flow may be limited by the level of population density; crowded living conditions were found to be negatively associated with labour migration.
\end{abstract}

\section{INTRODUCTION}

As economic development occurs, the agricultural sector becomes less prominent relative to the industrial sector. This is a result of the low income elasticity of the demand for food; as per capita income increases, a diminishing share of the budget is allocated to agricultural products. In Pakistan, the Green Revolution greatly increased both agricultural production and income during the 1960s and 1970s [Chaudhry (1982)]. In spite of this achievement, growth in the industrial sector outpaced that of agriculture, resulting in higher levels of urban labour demand, and thus higher wage rates and employment levels in the urban areas relative to the rural locations [Afzal (1967); United Nations (1988)].

Andrew P. Barkley is Assistant Professor in the Department of Agricultural Economics, Kansas State University, Manhattan, Kansas.

Author's Note: This research was conducted while I was associated with the Department of Economics, Quaid-i-Azam University, Islamabad, Pakistan. I wish to acknowledge the helpful comments of Dr M. Ghaffar Chaudhry, the referees of the PDR, and the participants of a lecture-discussion group that I had at the Pakistan Institute of Development Economics on December 3, 1990. 
The movement of labour from one location to another in Pakistan has increased in recent years. In the development literature, a concern has been expressed about the possibility of disequilibrium migration: labour migration that distorts rather than enhances economic efficiency. Todaro (1969) concluded that the rural-to-urban migration could lead to high levels of urban unemployment. This concern is reflected in the policy statement of the Government of Pakistan: “... comprehensive regional plans should be prepared with the objective of achieving a better rural-urban balance, slow down unnecessary and wasteful migration, distribute urbanization more uniformly, and accelerate the growth of small towns and intermediate cities" [Government of Pakistan (1978)].

Much can be learned about the causes and consequences of labour migration in Pakistan by an econometric analysis of the available Census data. The objective of this study is to garner knowledge concerning the movement of labour within Pakistan by identifying and quantifying the socio-economic determinants of labour in-migration between administrative districts during the 1970s. Specifically, an empirical model is formulated, based on the expected determinants of labour inmigration and data availability, and tested by using multiple regression analysis.

This paper proceeds as follows; the following section reviews previous literature pertinent to labour migration in Pakistan. The empirical specification of a macro-level migration function is presented in Section 3. Section 4 presents the results of the regression analysis, and the final section presents policy implications and conclusions.

\section{REVIEW OF LITERATURE}

The literature concerning the migration of labour in the developing nations is truly immense. The number of studies of migration virtually exploded after the development of the Todaro model in 1969. Todaro theorized that rapid urbanization was the result of rational economic behaviour by potential migrants, who compare expected modern (urban) sector incomes with current wages in rural occupations. The model has been extended, tested, confirmed by some, and rejected by others both theoretically and empirically. Excellent surveys of the literature are Todaro (1976); Fields (1975) and Yap (1977).

Several previous studies have been conducted on the migration of labour in Pakistan. Afzal $(1967,1974)$ surveyed (1) the sources of population change, (2) the movement of labour across international boundaries, and (3) internal migration during the period since the establishment of Pakistan as an independent country in 1947. Irfan et al. (1979); Irfan (1986) continued the examination of changes in employment by conducting a comprehensive survey on "Population, Labour Force, and Migration" in the 1970s. This survey established that "internal migration in 
Pakistan is becoming increasingly long-distance and rural-to-urban in orientation" [Irfan (1986), p. 61].

Rural-to-urban migration in India was investigated by Banerjee and Kanbur (1981). The authors used Census data to test an extended version of the Todaro model. The results indicated that "programmes which reduce poverty will stimulate migration, but those aimed at reducing inequality in landholdings will reduce migration". Banerjee (1981) emphasized the importance of family considerations on mobility decisions of the rural-to-urban migrants in India with an evaluation of the urban-rural ties that develop between migrants and family members who remain at the original location. Labour flows in Pakistan were studied by Nabi (1984), who employed village-level data to estimate the impact of "push" factors on migration. He concluded, "village-end variables are important in influencing the decision to migrate" (p. 142).

Convictions on the economic impact of urbanization and changing employment patterns in Pakistan are varied and contentious. The International labour Organization concluded that "the employment problem facing the country is both real and serious to merit immediate attention" (p. v), while a United Nations report claimed that "the pace of urbanization has been moderate", and "Migration rates are relatively low" (p. 50). One objective of this study is to critically evaluate both extreme views based on statistical evidence of the available macro-level data.

\section{SPECIFICATION OF A MIGRATION FUNCTION}

Migration data for Pakistan is available in the 1981 Census of Population Report for three periods; 1971-1975, 1976-1980, and 1971-1980. Provincial inmigration levels are summarized in Table 1 and in-migration levels by district are presented in Table 2. District in-migration rates employed in this study are the percentage of total population that has migrated into a given district, divided by the population of the receiving district, as summarized in Table 3 (a detailed description of the data can be found in the Data Appendix).

Previous studies [Barkley (1990); Cebula and Gatons (1973); Mundlak (1979)] used the wage or income levels and other economic variables, such as unemployment rates, as explanatory variables. No readily available estimates of economic variables such as wage rates, value-added, or per capita Gross Domestic Product exist at the district level. Based on these data limitations, migration into a given district in time $t\left(M R_{t}\right)$ is considered to be a function of socio-economic variables $(S O C I O)$, proxies for the costs of migration $(C)$, and the level of previous migration $\left(M R_{t-1}\right)$, as in Equation (1), and explained further below.

$$
M R_{t}=f\left(S O C I O_{\imath}, C_{t}, M R_{t-1}\right)
$$


Table 1

Migration Levels and Rates in Pakistan, 1971-1980

\begin{tabular}{lccr}
\hline & $1971-1975$ & $1975-1980$ & $1971-1980$ \\
\hline \multicolumn{4}{c}{ Migration Levels } \\
Pakistan & $1,178,138$ & $2,250,715$ & $3,428,853$ \\
Balochistan & 43,316 & 124,026 & 167,342 \\
N.W.F.P. & 72,057 & 277,260 & 349,317 \\
Punjab & 658,182 & $1,268,285$ & $1,926,467$ \\
Sindh & 404,583 & 581,144 & 985,727 \\
& Migration Rates & \\
Pakistan & 0.019 & 0.036 & 0.055 \\
Balochistan & 0.018 & 0.051 & 0.069 \\
N.W.F.P. & 0.009 & 0.033 & 0.041 \\
Punjab & 0.018 & 0.034 & 0.051 \\
Sindh & 0.029 & 0.041 & 0.070 \\
\hline
\end{tabular}

Note: A migrant is defined as a person who has moved from one administrative district to another administrative district. This definition excludes persons who have moved within a district. The migration rate is calculated as the migration level divided by the 1972 Census Population.

This study concentrates on the characteristics of the receiving district as explanatory variables; these are referred to as "pull" factors in the migration literature. Migration decisions depend on both "push" and "pull" factors. Due to data limitations, the place of origin of migrants in Pakistan is not known, resulting in the concentration on the receiving district. Note that the measure of labour migration is for in-migration only; the number of out-migrants is unavailable from Census data.

The socio-economic factors (SOCIO) included in the empirical study are disaggregated into educational variables (EDU), infrastructure variables (INFRA), urbanization $(U R B)$, population characteristics $(P O P)$, and proxies of the cost of migration (COST), as specified in Equation (2).

$$
M R_{t}=f\left(E D U_{t-1}, I N F R A_{t-1}, U R B_{t-1}, \operatorname{POP}_{t-1}, \operatorname{COST}_{t-1}, M R_{t-1}\right) \quad \ldots
$$

Many of the socio-economic variables included in the analysis are expected 
Table 2

District Migration Levels in Pakistan: Summary Statistics

\begin{tabular}{|c|c|c|c|c|}
\hline & Mean & S. D. & $\operatorname{Max}$ & Min \\
\hline \multicolumn{5}{|c|}{ District Migration Levels, 1971-1975 } \\
\hline Pakistan & 19,002 & 38,251 & 281,986 & 108 \\
\hline Balochistan & 2,707 & 4,591 & 14,670 & 108 \\
\hline N.W.F.P. & 6,005 & 7,522 & 27,874 & 123 \\
\hline Punjab & 31,342 & 19,707 & 87,457 & 6349 \\
\hline Sindh & 31,122 & 75,919 & 281,986 & 858 \\
\hline \multicolumn{5}{|c|}{ District Migration Levels, 1976-1980 } \\
\hline Pakistan & 36,302 & 51,708 & 336,719 & 322 \\
\hline Balochistan & 7,752 & 15,619 & 64,253 & 322 \\
\hline N.W.F.P. & 23,105 & 30,721 & 114,015 & 1,216 \\
\hline Punjab & 60,395 & 35,761 & 170,233 & 16,839 \\
\hline Sindh & 44,703 & 89,088 & 336,719 & 3,179 \\
\hline \multicolumn{5}{|c|}{ District Migration Levels, 1971-1980 } \\
\hline Pakistan & 55,304 & 88,872 & 618,705 & 672 \\
\hline Balochistan & 10,459 & 19,662 & 78,923 & 672 \\
\hline N.W.F.P. & 29,110 & 38,084 & 141,889 & 1339 \\
\hline Punjab & 91,737 & 54,801 & 257,690 & 23,188 \\
\hline Sindh & 75,825 & 164,877 & 618,705 & 4037 \\
\hline
\end{tabular}

Note: Karachi is considered one observation, although it is composed of three administrative districts.

to be highly correlated to the level of economic development in a given region. For this reason, economic variables are implicitly included in the empirical analysis. For example, high levels of education and infrastructure are likely to be associated with higher per capita incomes, and reflect in part the level of economic advancement of the district.

Once migration has taken place, the migrants become part of the population in a district. In the empirical analysis, statistical bias would result if the explanatory variables and the dependent variables were measured in the same time-period. To avoid simultaneity, the explanatory variables are lagged one period. Intuitively, this means that migration between periods $t$ and $t+1$ (say 1971 and 1980) is a function of the pre-determined characteristics of the receiving district in period $t$ (in this case 1971). The independent variables are considered briefly below, and in 
Table 3

District Migration Rates in Pakistan: Summary Statistics

\begin{tabular}{|c|c|c|c|c|}
\hline & Mean & S. D. & $\operatorname{Max}$ & Min \\
\hline \multicolumn{5}{|c|}{ District Migration Rates, 1971-1975 } \\
\hline Pakistan & 0.014 & 0.015 & 0.078 & 0.001 \\
\hline Balochistan & 0.014 & 0.021 & 0.068 & 0.002 \\
\hline N.W.F.P. & 0.008 & 0.006 & 0.017 & 0.001 \\
\hline Punjab & 0.017 & 0.008 & 0.034 & 0.006 \\
\hline Sindh & 0.016 & 0.020 & 0.078 & 0.002 \\
\hline \multicolumn{5}{|c|}{ District Migration Rates, $1976-1980$} \\
\hline Pakistan & 0.033 & 0.035 & 0.255 & 0.005 \\
\hline Balochistan & 0.040 & 0.062 & 0.255 & 0.005 \\
\hline N.W.F.P. & 0.028 & 0.020 & 0.066 & 0.008 \\
\hline Punjab & 0.034 & 0.014 & 0.066 & 0.017 \\
\hline Sindh & 0.028 & 0.024 & 0.093 & 0.006 \\
\hline \multicolumn{5}{|c|}{ District Migration Rates, 1971-1980 } \\
\hline Pakistan & 0.047 & 0.047 & 0.313 & 0.007 \\
\hline Balochistan & 0.053 & 0.079 & 0.313 & 0.010 \\
\hline N.W.F.P. & 0.035 & 0.025 & 0.082 & 0.008 \\
\hline Punjab & 0.051 & 0.021 & 0.100 & 0.024 \\
\hline Sindh & $0.044^{\circ}$ & 0.043 & 0.172 & 0.007 \\
\hline
\end{tabular}

Source: [Govemment of Pakistan (1972, 1981).]

Note: The migration rate is defined as the number of migrants into a district divided by the Census district population in 1972.

detail in the Data Appendix.

The level of education in a district is measured by the number of high schools per capita (HS), the number of colleges per capita (COL), and the district literacy rate (LIT), as summarized in Table 4. It is expected that higher levels of education will be positively associated with greater migration rates for two reasons. First, higher levels of education indicate greater economic development in a district; and second, since migrants are typically better educated, they are expected to be attracted to areas where their children will be able to acquire education. Many persons are motivated to educate their children in order to better the children's earning ability, providing a strong incentive to make migration decisions based on 
Table 4

Independent Variables Used to Explain Migration Rates in Pakistan:

Summary Statistics

\begin{tabular}{lrrrr}
\hline & Mean & S. D. & Max & Min \\
\hline \multicolumn{4}{c}{ Colleges per Capita (COL) } \\
Pakistan & $4.75 \mathrm{E}-06$ & $3.04 \mathrm{E}-06$ & $1.41 \mathrm{E}-05$ & \\
Balochistan & $4.35 \mathrm{E}-06$ & $4.03 \mathrm{E}-06$ & $1.19 \mathrm{E}-05$ & 0 \\
N.W.F.P. & $4.06 \mathrm{E}-06$ & $3.18 \mathrm{E}-06$ & $1.27 \mathrm{E}-05$ & 0 \\
Punjab & $4.73 \mathrm{E}-06$ & $2.20 \mathrm{E}-06$ & $9.73 \mathrm{E}-06$ & $1.92 \mathrm{E}-06$ \\
Sindh & $5.93 \mathrm{E}-06$ & $2.66 \mathrm{E}-06$ & $1.41 \mathrm{E}-05$ & $3.69 \mathrm{E}-06$ \\
& & & & \\
& & & & \\
Pakistan & Population Density (Persons per Km $\mathbf{m}^{2}$ ) (DENS) & \\
Balochistan & 404.21 & 491.24 & 2648 & 3 \\
N.W.F.P. & 29.38 & 28.25 & 94 & 3 \\
Punjab & 411.42 & 328.81 & 1120 & 28 \\
Sindh & 665.29 & 464.40 & 1694 & 111 \\
& 437.15 & 677.75 & 2648 & 93
\end{tabular}

High Schools per Capita (HS)

Pakistan

Balochistan

N.W.F.P.

Punjab

Sindh
$3.84 \mathrm{E}-05$

$$
2.16 \mathrm{E}-05
$$

1.13E- 04

$3.76 \mathrm{E}-05$

2.27E- 05

$8.16 \mathrm{E}-05$

5.49E- 05

2.33E- 05

1.13E- 04

$3.28 \mathrm{E}-05$

1.71E-05

8.98E- 05

$3.29 \mathrm{E}-05$

$1.97 \mathrm{E}-05$

9.57E- 05

5.05E- 06

$5.05 \mathrm{E}-06$

$3.49 \mathrm{E}-05$

$1.28 \mathrm{E}-05$

1.77E- 05

Pakistan

Balochistan

N.W.F.P.

Punjab

Sindh
0.169

0.087

0.141

0.202

0.242
0.093

0.061

0.048

0.084

0.088
0.512

0.239

0.204

0.428

0.512
0.056

0.056

0.058

0.106

0.154

Post Offices per Capita (PO)

Pakistan

Balochistan
$1.09 \mathrm{E}-04$
8.85E-05
6.24E- 04
$1.60 \mathrm{E}-05$
$6.25 \mathrm{E}-05$
2.10E- 05
$1.39 \mathrm{E}-04$
4.73E- 05 
Table $4-$ (Continued $)$

\begin{tabular}{|c|c|c|c|c|}
\hline & Mean & S. D. & $\operatorname{Max}$ & Min \\
\hline N.W.F.P. & $1.36 \mathrm{E}-04$ & $5.57 \mathrm{E}-05$ & $1.81 \mathrm{E}-04$ & $2.15 \mathrm{E}-05$ \\
\hline Punjab & $1.47 \mathrm{E}-04$ & $1.22 \mathrm{E}-04$ & $6.24 \mathrm{E}-04$ & $1.60 \mathrm{E}-05$ \\
\hline Sindh & $7.74 \mathrm{E}-05$ & $6.69 \mathrm{E}-05$ & $2.18 \mathrm{E}-04$ & $1.12 \mathrm{E}-05$ \\
\hline \multicolumn{5}{|c|}{ District Population in 1971 (Persons) (POP71) } \\
\hline Pakistan & $1,010,172$ & 908,908 & $4,241,785$ & 57,000 \\
\hline Balochistan & 151,813 & 65,236 & 252,000 & 57,000 \\
\hline N.W.F.P. & 702,965 & 467,032 & $1,730,923$ & 159,000 \\
\hline Punjab & $1,790,960$ & 839,330 & $2,241,785$ & 981,734 \\
\hline Sindh & $1,088,916$ & 818,354 & $3,606,746$ & 546,849 \\
\hline \multicolumn{5}{|c|}{ Roads per Square Km (Km Road per $\mathrm{Km}^{2}$ ) (ROAD) } \\
\hline Pakistan & 0.199 & 0.219 & 1.542 & 0.019 \\
\hline Balochistan & 0.068 & 0.040 & 0.157 & 0.019 \\
\hline N.W.F.P. & 0.159 & 0.065 & 0.325 & 0.106 \\
\hline Punjab & 0.261 & 0.160 & 0.616 & 0.033 \\
\hline Sindh & 0.296 & 0.392 & 1.542 & 0.022 \\
\hline \multicolumn{5}{|c|}{ District Urban Population (Percent) (URB) } \\
\hline Pakistan & 0.187 & 0.178 & 0.975 & 0 \\
\hline Balochistan & 0.158 & 0.157 & 0.627 & 0.010 \\
\hline N.W.F.P. & 0.091 & 0.092 & 0.278 & 0 \\
\hline Punjab & $0.221^{-}$ & 0.163 & 0.850 & 0.077 \\
\hline Sindh & 0.258 & 0.246 & 0.975 & 0.098 \\
\hline \multicolumn{5}{|c|}{$\begin{array}{l}\text { Dummy for Urban Population Greater than } 80 \\
\text { Percent }(1=\text { URB }>0.80 ; 0=\text { URB }<0.80) \text { (URB1) }\end{array}$} \\
\hline Pakistan & 0.048 & 0.216 & 1 & 0 \\
\hline Balochistan & 0.063 & 0.250 & 1 & 0 \\
\hline N.W.F.P. & 0 & 0 & 0 & 0 \\
\hline Punjab & 0.048 & 0.218 & 1 & 0 \\
\hline Sindh & 0.077 & 0.277 & 1 & 0 \\
\hline
\end{tabular}

Source: [Govemment of Pakistan $(1972,1981)$.]

Note: The migration rate is defined as the number of migrants into a district divided by the district population in 1972. 
both economic conditions and the availability of education in the receiving sector.

The level of infrastructure in a district is included in the regression analysis as a proxy for economic conditions in the district. The public provision of services such as communication and transportation facilities are associated with higher levels of income in a given area. The number of post offices per capita (PO) and the length of roads built per square kilometre (ROAD) are included in the model as measures of infrastructure. Both variables are expected to be positively associated with migration into a district.

The level of urbanization of a district is anticipated to be an important determinant of in-migration, because economic development is accompanied by the movement of workers from agricultural to urban employment. Two measures of urbanization are included in the regression analysis; first, the percentage of district population that lives in the urban areas (URB), and second, a dummy variable that equals one if the urban population is greater than sixty percent and zero if URB is less than sixty percent. This variable provides a second measure of the three most urbanized districts: Karachi (97 percent urban), Lahore (85 percent urban), and Quetta (63 percent urban).

The level and type of the population in a district may influence the rate of in-migration. A greater number of persons within a province reflects a larger economic base, and thus larger absorptive ability for immigrants [Mundlak (1979)]. In one specification of the model, the level of population in 1971 (POP 71) is included as an explanatory variable to capture any impact that population size might have on the flow of labour into a district. Population density (DENS) reflects the living conditions in the receiving district, and may influence migration. A priori predictions about the effect of DENS on migration are not forthcoming, since a higher population density may reflect greater absorptive ability and thus higher migration rates, or it may reflect crowded conditions that are avoided in the migration process.

Banerjee (1981) found a positive relationship between the previous levels of migration and current migration, and indicated that a measure of the level of previous migrants to a given location is often included in the estimation of migration functions as a proxy for lower costs associated with the transition to a new location. The Population Census of Pakistan provides the number of migrants living in a district for the years 1947-1970, in addition to the number of migrants during the 1970s. The rate of previous migration into a district (PREMIG) is included in the model to capture the dynamic link between the previous and current migrants.

The four provinces in Pakistan are diverse in both social and economic conditions, as can be seen by comparing the socio-economic indicators in Table 4. To capture any systematic differences in the rates of migration between the provinces that are not captured by the other explanatory variables, dummy variables are 
included for the provinces of Balochistan (BALO), the North-West Frontier Province (NWFP), and Sindh (SINDH). The Punjab was selected as the default province because it is characterized by the highest migration levels in Pakistan.

The independent variables described above may exhibit multicollinearity because the included variables all measure aspects of socio-economic development at the district level. To test for multicollinearity, two techniques were utilized. First, correlation coefficients were calculated and are reported in Table 5. Positive correlations were present between several of the variables. However, severe multicollinearity was not present because all of the coefficients are below 0.8 [Judge $e t$ al. (1982)]. Note that the variables URB and URB1 were used as alternative measures of urbanization, and were not included in the same regression.

Second, a more complete analysis of multicollinearity was performed using regression diagnostics to evaluate the regressors of the model for potentially degrading multicollinearity [Belsley et al. (1980)]. The results of this procedure are discussed in the following section, which presents and discusses the regression results.

Table 5

Correlation Coefficients of Independent Variables

\begin{tabular}{|c|c|c|c|c|c|c|c|c|c|c|}
\hline & PREMIG & URB & URB1 & DENS & HS & $\mathrm{COL}$ & LIT & PO & ROAD & POP71 \\
\hline PREMIG & 1.000 & & & & & & & & & \\
\hline URB & 0.520 & 1.000 & & & & & & & & \\
\hline URB1 & 0.443 & 0.804 & 1.000 & & & & & & & \\
\hline DENS & 0.661 & 0.609 & 0.497 & 1.000 & & & & & & \\
\hline HS & 0.068 & 0.254 & 0.318 & 0.260 & 1.000 & & & & & \\
\hline $\mathrm{COL}$ & 0.282 & 0.584 & 0.506 & 0.352 & 0.359 & 1.000 & & & & \\
\hline LTT & 0.501 & 0.640 & 0.464 & 0.692 & 0.334 & 0.576 & 1.000 & & & \\
\hline PO & -0.025 & 0.076 & -0.121 & 0.130 & 0.231 & 0.089 & 0.340 & 1.000 & & \\
\hline ROAD & 0.508 & 0.589 & 0.438 & 0.734 & 0.350 & 0.435 & 0.723 & 0.200 & 1.000 & \\
\hline POP71 & 0.640 & 0.473 & 0.285 & 0.772 & -0.033 & 0.168 & 0.555 & 0.138 & 0.639 & 1.000 \\
\hline
\end{tabular}

Nore: See Data Appendix for sources; see Table 4 for descriptive statistics of variables. 


\section{RESULTS}

Migration levels and rates in Pakistan are low relative to the other developing nations in Asia [United Nations (1988), p. 50]. However, the incidence of migration increased during the 1970s (Tables 1 and 2). Ordinary least squares regression was used to identify the socio-economic variables that determine the variation in the migration rates across districts. Three time-periods were considered; the decade 1971-1980 (Table 6), and two five-year periods, 1971-1976 (Table 7) and 1976-1980 (Table 8). The overall results are similar for all three periods, but some differences were found between the two five-year periods. Much of the variation in migration rates was explained, as indicated by the relatively high $R$-square values between 0.53 to 0.85 .

Several different regression trials were run based on the potential for multicollinearity. The population variable (POP71) was positively associated with the variables PREMIG, DENS, and ROAD (Table 5). For this reason, POP71 was included in one of the three regressions reported for each time-period.

A statistical test for multicollinearity was performed for each of the nine regressions reported. The regression coefficient variance decomposition procedure of [Belsley et al. (1980), pp. 98-114] was employed to test for potential degrading (nearly) collinear relationships. In all regressions, multicollinearity was not present based on low condition indices and variance decomposition proportions among two or more estimated regression cocfficients.

The costs of migration are expected to be lowered if a district is associated with a larger number of previous migrants (PREMIG). The regression results provide evidence that prior migration rates are positively associated with current migration rates at a high degree of statistical significance in all of the regression trials. Simply stated, this implies that migration in the future is more likely to occur where migration has taken place in the past; there is inertia to the movement of labour due to family ties and other linkages between the areas of origin and the receiving areas that reduce both pecuniary and psychic costs of migration. The strong relationship between the past and the present migration rates indicates persistence of the underlying determinants of in-migration. For example, wage differentials may persist during the course of economic development, resulting in a continued flow of labour into regions of economic growth.

Urbanization is also found to be positively related to interdistrict migration rates. The regression results indicate a high degree of statistical significance for both measures of urbanization, URB and URB1. The dummy variable that includes only the districts with extremely high levels of urbanization (URB1) was statistically significant at a higher level than the percentage of the urban population in each district (URB) in all three sets of regressions. This indicates that much of the 
Table 6

Regression Results to Explain Interdistrict In-migration Rates in Pakistan, 1971-1980

\begin{tabular}{|c|c|c|c|}
\hline \multirow[b]{2}{*}{ Independent Variable } & \multicolumn{3}{|c|}{ District In-migration Rate, $1971-1980$} \\
\hline & (1) & (2) & (3) \\
\hline INTERCEPT & $\begin{array}{l}-0.028^{*} \\
(-1.805)\end{array}$ & $\begin{array}{l}-0.023 \\
(-1.060)\end{array}$ & $\begin{array}{l}-0.001 \\
(-0.038)\end{array}$ \\
\hline PREMIG & $\begin{array}{l}0.542^{* * *} \\
(5.723)\end{array}$ & $\begin{array}{l}0.544^{* * * *} \\
(5.689)\end{array}$ & $\begin{array}{l}0.486^{* * *} \\
(6.035)\end{array}$ \\
\hline URB & $\begin{array}{l}0.114^{* * *} \\
(3.100)\end{array}$ & $\begin{array}{l}0.117^{* * *} \\
(3.091)\end{array}$ & - \\
\hline URB 1 & - & - & $\begin{array}{l}0.132 * * * \\
(5.877)\end{array}$ \\
\hline DENS & $\begin{array}{l}-6.53 \mathrm{E}-05^{* * *} \\
(-3.592)\end{array}$ & $\begin{array}{l}-6.25 E-05^{* * *} \\
(-3.182)\end{array}$ & $\begin{array}{l}-6.15 E-05^{* * *} \\
(-4.147)\end{array}$ \\
\hline HS & $\begin{array}{l}-79.317 \\
(-0.295)\end{array}$ & $\begin{array}{c}-101.228 \\
(-0.366)\end{array}$ & $\begin{array}{c}-120.172 \\
(-0.532)\end{array}$ \\
\hline $\mathrm{COL}$ & $\begin{array}{r}560.908 \\
(0.304)\end{array}$ & $\begin{array}{r}456.410 \\
(0.243)\end{array}$ & $\begin{array}{r}388.932 \\
(0.258)\end{array}$ \\
\hline LIT & $\begin{array}{c}0.207^{*} \\
(1.866)\end{array}$ & $\begin{array}{c}0.202^{*} \\
(1.799)\end{array}$ & $\begin{array}{c}0.126 \\
(1.327)\end{array}$ \\
\hline PO & $\begin{array}{l}-48.481 \\
(-0.801)\end{array}$ & $\begin{array}{l}-51.049 \\
(-0.832)\end{array}$ & $\begin{array}{l}30.973 \\
(0.594)\end{array}$ \\
\hline ROAD & $\begin{array}{c}0.016 \\
(0.499)\end{array}$ & $\begin{array}{c}0.020 \\
(0.604)\end{array}$ & $\begin{array}{c}0.022 \\
(0.828)\end{array}$ \\
\hline POP71 & - & $\begin{array}{l}-4.01 \mathrm{E}-09 \\
(-0.397)\end{array}$ & - \\
\hline BALO & $\begin{array}{l}0.033^{* *} \\
(2.051)\end{array}$ & $\begin{array}{c}0.028 \\
(1.483)\end{array}$ & $\begin{array}{c}0.020 \\
(1.499)\end{array}$ \\
\hline NWFP & $\begin{array}{l}0.049 * * * \\
(2.892)\end{array}$ & $\begin{array}{l}0.046^{* *} \\
(2.560)\end{array}$ & $\begin{array}{l}0.033^{* *} \\
(2.329)\end{array}$ \\
\hline SINDH & $\begin{array}{l}-0.021 \\
(-1.439)\end{array}$ & $\begin{array}{l}-0.024 \\
(-1.475)\end{array}$ & $\begin{array}{l}-0.013 \\
(-1.072)\end{array}$ \\
\hline$R$-SQUARE & 0.635 & 0.636 & 0.742 \\
\hline ADJ. $R$-SQUARE & 0.554 & 0.547 & 0.685 \\
\hline$F$-STATISTIC & 7.900 & 7.133 & 13.104 \\
\hline Observations & 62 & 62 & 62 \\
\hline
\end{tabular}

Note: $t$-statistics are in parentheses. '***' indicates statistical significance at the 0.01 level; '**' the 0.05 level; and '*' the 0.10 level. 
Table 7

Regression Results to Explain Interdistrict In-migration Rates in Pakistan, 1971-1975

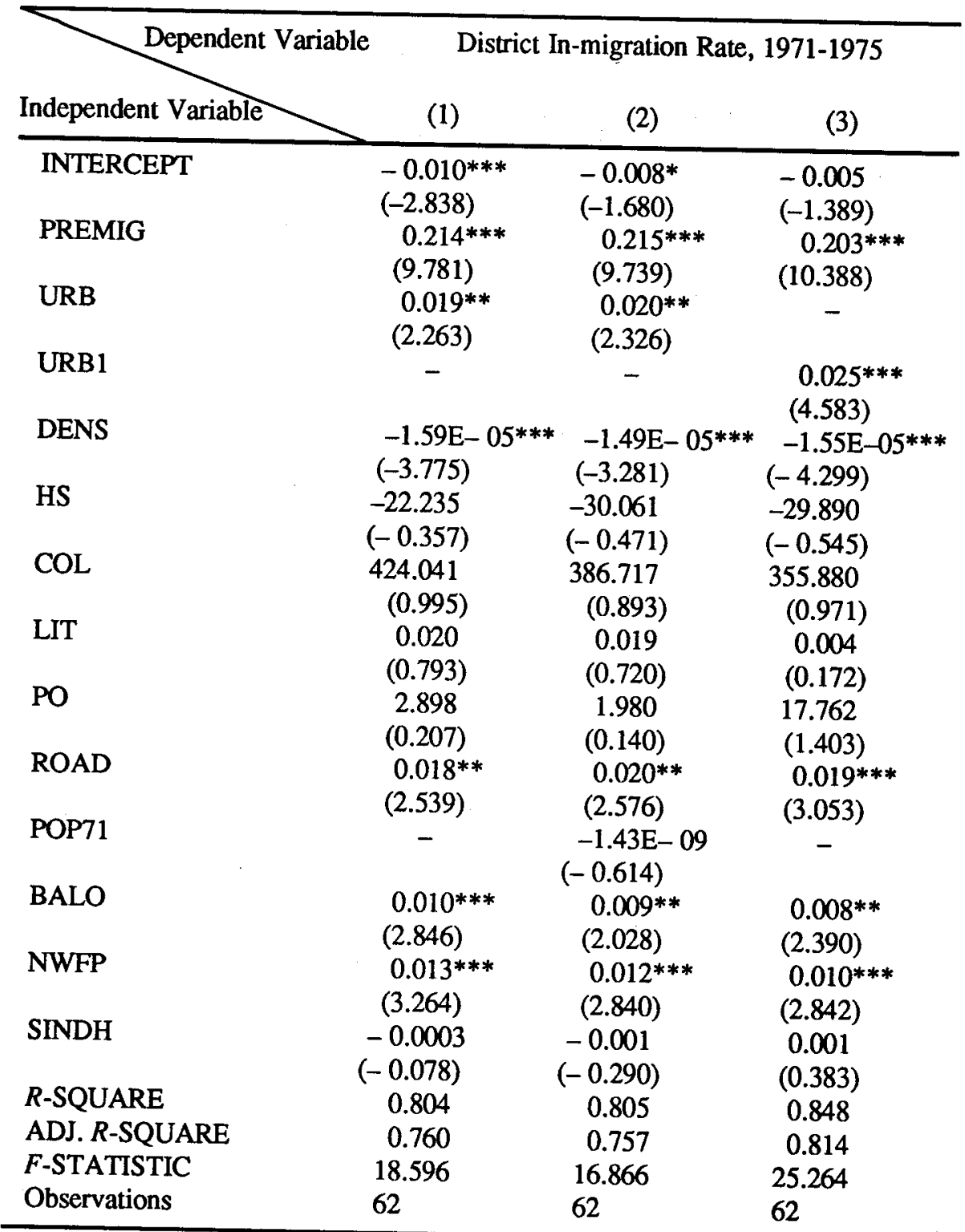

Note: $t$-statistics are in parentheses. '***' indicates statistical significance at the 0.01 level; '**' the 0.05 level; and '*' the 0.10 level. 
Table 8

Regression Results to Explain Interdistrict In-migration Rates in Pakistan, 1976-1980

\begin{tabular}{|c|c|c|c|}
\hline \multirow[b]{2}{*}{ Independent Variable } & \multicolumn{3}{|c|}{ District In-Migration Rate, 1976-1980 } \\
\hline & (1) & (2) & (3) \\
\hline INTERCEPT & $\begin{array}{l}-0.018 \\
(-1.370)\end{array}$ & $\begin{array}{l}-0.014 \\
(-0.802)\end{array}$ & $\begin{array}{c}-0.004 \\
(-0.350)\end{array}$ \\
\hline PREMIG & $\begin{array}{l}0.328^{* * *} \\
(4.128)\end{array}$ & $\begin{array}{l}0.329^{* * * *} \\
(4.101)\end{array}$ & $\begin{array}{l}0.283^{* * *} \\
(4.108)\end{array}$ \\
\hline URB & $\begin{array}{l}0.094^{* * *} \\
(3.073)\end{array}$ & $\begin{array}{l}0.096^{* * *} \\
(3.045)\end{array}$ & - \\
\hline URB1 & - & - & $\begin{array}{l}0.107^{* * *} \\
(5.572)\end{array}$ \\
\hline DENS & $\begin{array}{l}-4.95 \mathrm{E}-05^{* * *} \\
(-3.243)\end{array}$ & $\begin{array}{l}-4.77 \mathrm{E}-05^{* * *} \\
(-2.890)\end{array}$ & $\begin{array}{l}-4.60 \mathrm{E}-05^{* * *} \\
(-3.630)\end{array}$ \\
\hline HS & $\begin{array}{l}-57.082 \\
(-0.253)\end{array}$ & $\begin{array}{l}-71.167 \\
(-0.307)\end{array}$ & $\begin{array}{c}-90.281 \\
(-0.467)\end{array}$ \\
\hline $\mathrm{COL}$ & $\begin{array}{r}136.867 \\
(0.089)\end{array}$ & $\begin{array}{l}69.693 \\
(0.044)\end{array}$ & $\begin{array}{l}33.052 \\
(0.026)\end{array}$ \\
\hline LIT & $\begin{array}{l}0.187^{* *} \\
(2.007)\end{array}$ & $\begin{array}{c}0.184^{*} \\
(1.946)\end{array}$ & $\begin{array}{c}0.122 \\
(1.503)\end{array}$ \\
\hline $\mathrm{PO}$ & $\begin{array}{c}-51.378 \\
(-1.013)\end{array}$ & $\begin{array}{c}-53.029 \\
(-1.030)\end{array}$ & $\begin{array}{l}13.211 \\
(0.296)\end{array}$ \\
\hline ROAD & $\begin{array}{l}-0.003 \\
(-0.105)\end{array}$ & $\begin{array}{c}0.0003 \\
(0.012)\end{array}$ & $\begin{array}{c}0.002 \\
(0.102)\end{array}$ \\
\hline POP71 & - & $\begin{array}{l}-2.58 \mathrm{E}-09 \\
(-0.304)\end{array}$ & - \\
\hline BALO & $\begin{array}{c}0.022^{*} \\
(1.662)\end{array}$ & $\begin{array}{c}0.019 \\
(1.210)\end{array}$ & $\begin{array}{c}0.012 \\
(1.075)\end{array}$ \\
\hline NWFP & $\begin{array}{l}0.036^{* *} \\
(2.549)\end{array}$ & $\begin{array}{l}0.035^{* *} \\
(2.270)\end{array}$ & $\begin{array}{c}0.024^{*} \\
(1.917)\end{array}$ \\
\hline SINDH & $\begin{array}{l}-0.021^{*} \\
(-1.694)\end{array}$ & $\begin{array}{l}-0.023^{*} \\
(-1.678)\end{array}$ & $\begin{array}{l}-0.014 \\
(-1.362)\end{array}$ \\
\hline$R$-SQUARE & 0.532 & 0.533 & 0.657 \\
\hline ADJ. $R$-SQUARE & 0.429 & 0.418 & 0.581 \\
\hline F-STATISTIC & 5.166 & 4.657 & 8.695 \\
\hline Observations & 62 & 62 & 62 \\
\hline
\end{tabular}

Note: $t$-statistics are in parentheses. '***' indicates statistical significance at the 0.01 level; '**' the 0.05 level; and '*' the 0.10 level. 
movement of labour in Pakistan during the 1970s was towards urban industrial centres, confirming the expectation that the modern (urban) sector will grow relative to the rural (agricultural) sector, as has been evidenced in all economies during the process of development.

Some evidence on economic conditions in the urban versus the rural areas is available in the form of average per capita incomes and average household incomes in 1979 (Table 9). The evidence confirms the hypothesis that migration is a result of the movement of labour towards better economic circumstances; per capita incomes in the urban areas are higher in all provinces with the exception of Balochistan, which represents only a small fraction of the total population (Table 9).

Table 9

Provincial Average Income Levels in Pakistan, 1979

\begin{tabular}{lcccc}
\hline & $\begin{array}{c}\text { Average } \\
\text { per Capita } \\
\text { Income }\end{array}$ & $\begin{array}{c}\text { Average } \\
\text { Household } \\
\text { Income }\end{array}$ & $\begin{array}{c}\text { Percent of } \\
\text { Population } \\
\text { Poor }\end{array}$ & $\begin{array}{c}\text { Percent of } \\
\text { Population } \\
\text { Very Poor }\end{array}$ \\
\hline \multicolumn{5}{c}{ Average } \\
Pakistan & 163 & 992 & 36.9 & 26.5 \\
Balochistan & 185 & 1221 & 58.6 & 47.8 \\
N.W.F.P. & 163 & 1000 & 15.8 & 7.5 \\
Punjab & 151 & 897 & 38.9 & 28.1 \\
Sindh & 203 & 1354 & 42.6 & 31.5 \\
& & & & \\
Pakistan & 206 & 838 & 38.6 & 25.6 \\
Balochistan & 157 & 108 & 38.6 & 25.6 \\
N.W.F.P. & 203 & 196 & 29.6 & 17.3 \\
Punjab & 190 & 993 & 41.5 & 28.2 \\
Sindh & 246 & 541 & 32.3 & 20.3 \\
\hline
\end{tabular}

Source: Reproduced from Intemational Labour Organization (1983), Annexure I, Tables I.5 and I.7. Statistics taken from the Pakistan Household Income and Expenditure Survey, July-September, 1979.

Notes: 'The term 'poor' is defined as a monthly income of Rs 75 per month per adult equivalent. The term 'very poor' is defined as a monthly income of Rs 65 per month per adult equivalent.

bFor the NWFP, the whole of Malakand Division (i.e., districts of Swat, Dir, and Chitral) and all of the tribal areas are excluded from the sample. Since these are generally known to be much poorer regions of the province, the results lead to serious under-estimation of poverty in the NWFP and hence for the whole country. 
The literacy rate performed as expected during the second five-year period, 1976-1980, (Table 8) possibly due to an increase in the importance of education as a determinant of migration. The measures of high schools and colleges per capita were not found to be significantly associated with migration rates at the district level. This may be because the measures of high schools and colleges per capita are imperfect measures of the quality of education. The literacy rate (LIT), however, does capture quality of education to a degree, and was found to be a significantly positive determinant of migration in the second half of the decade and in the 10year regressions.

Higher levels of education (literacy) are concomitant with economic development, and also make the receiving district more attractive to parents concerned about the education of their children. Since migrants tend to be younger and better educated than non-migrants, it can be inferred that these characteristics indicate a concern for better educational facilities, and hence better economic opportunities, as the regression results demonstrate.

The development of local infrastructure may also influence the attractiveness of a district because of the relationship between infrastructure and economic development. The number of post offices per capita and the length of roads per square kilometre were included in the analysis as proxies for the ability of a district to absorb immigrants, the reduced moving costs associated with improved transportation and communication that the infrastructure provides, and the positive relationship between infrastructure and economic conditions within a district. Not too surprisingly, the number of post offices per capita (PO) was not a significant determinant of migration rates. However, the number of kilometres of roads in a district divided by the area in square kilometres in that district (ROAD) was found to be positively associated with migration in the first half of the 1970s (Table 7). This may reflect reliance on transportation as a prerequisite to economic growth, since the opportunity to trade is crucially linked to the transportation network. Migrants are expected to be attracted to areas of high economic growth, which often occurs together with the development of transportation.

Population characteristics provide some interesting results; while the level of population in a district (POP71) did not influence migration rates, population density (DENS) had a negative impact on the flow of labour into a given area. This outcome is best interpreted in the context of the multiple regression framework. The effect of urbanization is purged from the partial impact of density of migration rates due to the inclusion of the URB variable, indicating that given the level of urbanization in a district, the more dense districts are less attractive to migrants than the less crowded areas. This consequence is statistically significant at a high level, and provides the motivation for further work in labour migration in Pakistan: urbanization may proceed towards the less dense urban areas such as the Quetta, Loralai, 
and Sheikhupura districts in the future.

Regional differences in migration are uncovered by the inclusion of three dummy variables for Balochistan (BALO), the North-West Frontier Province (NWFP), and Sindh (SINDH). Sindh experienced lower rates of migration relative to the Punjab region during the period 1976-1980 (Table 8). Balochistan and the NWFP had relatively higher levels of migration, however the significance of these regional differences decreased during the period under consideration. This could be due to the influx of refugees from Afghanistan that occurred in the last two years of the decade: 1979-1980. Since that time, over three million Afghans migrated into the NWFP and Balochistan. The measurement problems associated with refugees should be emphasized, and any strong conclusions about this aspect of labour migration should be avoided.

Interestingly, per capita income in rural Balochistan exceeded urban incomes in that province, and household incomes in the rural areas of Balochistan and the NWFP exceeded those in the urban areas. However, it appears that much of the migration into these provinces is to the urban areas of Quetta and Peshawar. The average income data may not be reliable because of the aforementioned difficulty of counting refugees in both population data and income data.

The elasticities of each of the significant variables are calculated at the sample means, and presented in Table 10. The elasticities indicate that migration has become more responsive to the level of urbanization, population density, and literacy rates over time, yet the responsiveness of interdistrict migration to these variables is not large. This was expected, since the included variables do not exhibit large variation across districts. District level in-migration became less responsive to previous migration rates (PREMIG) during the 1970s. This is intuitively plausi-

Table 10

Elasticity Estimates of Interdistrict Migration in Pakistan, 1971-1980

\begin{tabular}{lccc}
\hline $\begin{array}{l}\text { Independent } \\
\text { Variable }\end{array}$ & $1971-1980$ & $1971-1975$ & $1976-1980$ \\
\hline PREMIG & 0.734 & 0.956 & 0.637 \\
URB & 0.453 & 0.248 & 0.534 \\
DENS & -0.560 & -0.449 & -0.608 \\
LIT & 0.743 & - & 0.961 \\
ROAD & - & 0.250 & - \\
\hline
\end{tabular}

Note: Elasticities are calculated at the sample means. The elasticities reported correspond to the estimated coefficients of Regression (1) in Tables 6, 7, and 8. 
ble because the impact of past events is expected to diminish over time. The next section provides conclusions for this empirical study.

\section{CONCLUSIONS}

The movement of labour in response to economic opportunities is inevitable. As economic growth occurs, the industrial sector will expand at a faster rate than the agricultural sector, resulting in a flow of labour out of the rural areas into the modern (urban) sector. In Pakistan, job creation has occurred in the rural areas with the advent of the Green Revolution [Chaudhry (1982)] and in the urban areas due to the process of industrialization [United Nations (1988)]. In the future, the low income elasticity of food ensures that the net flow of employment will be towards the urban areas.

Some evidence of the trend towards urbanization has been provided in the case of interdistrict labour in-migration in Pakistan during the 1970s. It has been shown that the level of urbanization exerts a positive influence of the rate of migration into a given administrative district. Given the level of urbanization, population density has a negative impact on the flow in labour. This may indicate that future migration may occur towards less dense cities where living conditions are less severe.

The percent of previous migrants in a district's population influenced migration decisions; one of the strong results forthcoming from this analysis is the ability to predict where future migration will occur: future migration will tend to locate in areas where previous migrants have located. Reduced monetary and psychic costs that are associated with the previous migrants exert a strong "pull" factor on current migrants. The relationship between the past and the present migration rates indicates that the underlying determinants of migration into a district that were present before 1970 persisted through the 1970 s.

Higher levels of education and infrastructure were positively associated with migration between districts, at least to the degree that higher levels of literacy and greater lengths of roads are positively related to migration rates. The strong motivation to educate children in order to enhance their economic opportunities was put forth as a possible cause of migration into areas where higher levels of education are available. Some regional variations in migration levels were uncovered. Specifically, Balochistan and the NWFP were characterized by relatively higher rates of migration, while Sindh had lower rates relative to migration into the Punjab.

Much is known about who is likely to migrate; previous studies in Pakistan and elsewhere provided evidence on the personal characteristics that are associated with higher levels of migration. The contribution of this effort is the analysis of the 
influence that socio-economic variables in the receiving district have on interdistrict migration rates. Several of the included socio-economic variables exerted significant influence on the rate at which persons change residence in Pakistan. These results, together with the limited evidence on average per capita incomes, allow for the tentative conclusion that migration appears to be a decision undertaken by rational economic agents in order to better their economic circumstances. The results imply that future migration is likely to continue to those districts that have a relatively high urban population, higher literacy rates and infrastructure development, and more previous migrants relative to other areas.

\section{DATA APPENDIX}

Appendix

The basic sources of data for this study are the Population Censuses of Pakistan, 1972 and 1981. The research is restricted to inter-provincial in-migration; a migrant is defined as a person who has moved from one administrative district to another administrative district. The three administrative districts within the city of Karachi are considered as a single observation due to data limitations. The Federally Administered Tribal Areas (FATA), Azad Kashmir, the Northern Areas, the Federal Capital Territory of Islamabad, and Occupied Kashmir were excluded from the analysis due to data limitations. The total number of observations (districts) included in the regression analysis is sixty-two.

\section{Dependent Variables}

Three sets of regression trials are presented in this analysis; one set for the period 1971-1980, and one set each for the five-year periods of 1971-1975 and 1976-1980. The ten-year migration rate is calculated by dividing the number of persons who moved into a district between 1971 and 1980 by the 1971 estimate of district population. The five-year migration rates are calculated similarly. These variables are summarized in Table 2.

\section{Independent Variables}

Due to a lack of available data on economic measures such as the GDP per capita, unemployment, or value-added at the district level in Pakistan, socio-economic variables are utilized as independent variables. Most of the variables included are taken from the 1972 Census of Population, and the remainder from the 1981 Census of Population. One limitation exists with the socio-economic variables; twenty-nine of the sixty-two administrative districts in Pakistan included here were re-defined by the 1981 Census. Thus, the socio-economic variables that are taken from the 1972 Census were re-calculated based on the 1981 Census definitions for 
the re-defined districts. The variables PREMIG, URB, URB1, and POP71 are unaffected by this change in definitions, because the source of these variables is the 1981 Census. Below, these independent variables are defined and described.

PREMIG (Source: 1981 Population Census) is defined as the rate of migration into a district between Partition (1947) and 1971. This measure of previous migrants includes all original migrants from India during the birth of Pakistan. The variable is calculated by dividing the number of migrants that arrived in a district between 1947 and 1971 by the district's 1971 population.

URB (Source: 1981 Population Census) is the level of urbanization, defined as the percentage of district population living in an urban area. An urban area is defined by the Population Census as all localities which were either metropolitan corporation, municipal committce, town committee or cantonment at the time of the census. URB 1 is a qualitative (dummy) variable that equals one when the percent of urban population in a district is greater than sixty percent and equals zero when the percentage of urban population is less than sixly percent.

DENS (Source: 1972 Population Census) is population density, or the number of persons per square kilometre within a district's boundaries.

HS (Source: 1972 Population Census) is the number of high schools in an administrative district divided by the 1971 district population.

COL (Source: 1972 Population Census) is the number of colleges in an administrative district divided by the 1971 district population.

LIT (Source: 1972 Population Census) is the rate of literacy in an administrative district in percentage terms.

PO (Source: 1972 Population Census) is the number of post offices per capita. It is defined as the number of post offices in an administrative district divided by the 1971 population.

ROAD (Source: 1972 Population Census) is a measure of the number of kilometres of road (both metalled and unmetalled) in a district, divided by the area of the district in square kilometres.

POP71 (Source: 1981 Population Census) is the 1971 Census population of a district. Note that this is an estimate of the re-defined 1981 districts.

\section{REFERENCES}

Afzal, Mohammad (1967) Migration and Supply of Non-agricultural Male Labour Force in the Cities of Pakistan, 1951-61. A paper presented to the Seminar on 'Population Problems in the Economic Development of Pakistan', held at the Pakistan Institute of Development Economics, Karachi, June 2-3.

Afzal, Mohammad (1974) The Population of Pakistan. Islamabad: Pakistan Institute of Development Economics. Committee for International Coordination 
of National Research in Demography (CICRED).

Banerjee, Biswajit (1981) Rural-Urban Migration and Family Ties: An Analysis of Family Considerations in Migration Behavior in India. Oxford Bulletin of Economics and Statistics 43 : 321-356.

Banerjee, B., and S. M. Kanbur (1981) On the Specification and Estimation of Macro Rural-Urban Migration Functions: With an Application to Indian Data. Oxford Bulletin of Economics and Statistics 43 : 7-30.

Barkley, Andrew P. (1990) The Determinants of the Migration of Labor out of Agriculture in the United States; 1940-1985. American Journal of Agricultural Economics 72 : 567-573.

Belsley, David A., Edwin Kuh and Roy E. Welsch (1980) Regression Diagnostics. New York: John Wiley and Sons.

Cebula, Richard J., and Paul K. Gatons (1973) Intersectoral Factor Prices and Mobility. Pakistan Economic and Social Review $11: 207-214$.

Chaudhry, M. Ghaffar (1982) Green Revolution and Redistribution of Rural Incomes: Pakistan's Experience. The Pakistan Development Review 21 : 3 173-205.

Fields, Gary S. (1975) Rural-Urban Migration, Urban Unemployment and Underemployment, and Job-Search Activity in LDCs. Journal of Development Economics 2 : 165-187.

International Labour Organization (1983) Employment and Structural Change in Pakistan - Issues for the Eighties. Asian Regional Team for Employment Promotion. The Asian Employment Programme.

Irfan, Mohammad (1986) Migration and Development in Pakistan: Some Selected Issues. The Pakistan Development Review $25: 4$ 743-755.

Irfan, Mohammad, Lionel Demery and Ghulam Mohammad Arif (1979) Migration Patterns in Pakistan: Preliminary Results from the PLM Survey. Islamabad: Pakistan Institute of Development Economics. (Studies in Population, Labour Force and Migration. Project Report Number 6.)

Judge, George G., R. Carter Hill, William E. Griffiths, Helmut Lutkepohl and Tsoung-Chao Lee (1982) Introduction to the Theory and Practice of Econometrics. New York: John Wiley and Sons.

Mundlak, Yair (1979) Intersectoral Factor Mobility and Agricultural Growth. Washington, D. C.: International Food Policy Research Institute.

Nabi, Ijaz (1984) Village-end Considerations in Rural-Urban Migration. Journal of Development Economics 14 : 129-145.

Pakistan, Government of (1978) The Fifih Five Year Plan 1978-1983. Karachi: The Planning Commission.

Pakistan, Government of (1989) National Migration Survey 1984. Islamabad: Federal Bureau of Statistics, Statistics Division. 
Pakistan, Government of $(1972,1981)$ Census Report of Pakistan. Islamabad: Population Census Organization, Statistics Division.

Todaro, M. P. (1969) A Model of Labor Migration and Urban Unemployment in Less Developed Countries. American Economic Review 59 : 138-148.

Todaro, M. P. (1976) Internal Migration in Developing Countries: A Review of Theory, Evidence, Methodology, and Research Priorities. Geneva: International Labour Organization.

United Nations (1988) Trends in Migration and Urbanization in Selected ESCAP Countries. Bangkok, Thailand: Economic and Social Commission for Asia and the Pacific. (Asian Population Studies Series No. 89.)

Yap, L. Y. L. (1977) The Attraction of the Cities: A Review of Migration Literature. Journal of Development Economics 4 :239-264. 